\title{
HUBUNGAN ANTARA KOMUNIKASI INTERPERSONAL MARKETING DAN MEMBER DENGAN BRAND IMAGE HOTEL
}

\section{RELATIONS BETWEEN INTERPERSONAL COMMUNICATION MARKETING AND MEMBERS WITH BRAND IMAGE HOTEL}

\author{
M Qodriyyah1, Sukarelawati², AA Kusumadinata ${ }^{3 a}$
}

\begin{abstract}
${ }^{1}$ Alumni Ps. Ilmu Komunikasi, Fakultas Ilmu Sosial dan Ilmu Politik, Universitas Djuanda Bogor, ${ }^{2}$ Dosen Pembimbing I Program Studi Komunikasi, Fakultas Ilmu Sosial dan Ilmu Politik, ${ }^{3}$ Dosen Pembimbing II Program Studi Komunikasi Universitas Djuanda Bogor, Jl. Tol Ciawi No.1 Kotak Pos 35 Bogor 16720 a Korespondensi: AA Kusumadinata, Email: alialamsyahkusumadinata@gmail.com
\end{abstract}

(Diterima: 07-05-2015; Ditelaah: 10-06-2015; Disetujui: 13-08-2015)

\begin{abstract}
The purpose of this study is to; (1) Assess your interpersonal communication conducted by marketing the Hotel Santika Bogor members, (2) Assess the brand image of Hotel Santika Bogor, (3) Assessing the relationship between interpersonal communication marketing and members with Bogor Hotel Santika brand image. This type of research is associative research methods with quantitative approaches. The population in this study was 50 repeater guests who stayed at Hotel Santika Bogor. This population was obtained from the database of Hotel Santika Bogor, so it is a finite population (limited). Samples taken in this study were drawn from a known population of the database repeater (finite population) Hotel Santika Bogor, amounting to 50 samples. The sampling technique used is a saturated or census technique is to take the entire population. Calculation results obtained significance test tcount prices and $t_{\text {table }} 6.202$ to 0.05 with test error two parties, and $\mathrm{df}=\mathrm{n}-2=48$ obtained 2,021. This means there is a positive and significant relationship interpersonal communication marketing and members with Bogor Hotel Santika brand image. Interpersonal communication marketing of the members factors contributing and brand image is $44.5 \%$, while $55.5 \%$ are influenced by other factors, such as product differentiation, the use of celebrity endorser, event sponsorship, brand ambassador, leadership, and excellence of products.
\end{abstract}

Keywords: Interpersonal Communication, Brand Image

\begin{abstract}
ABSTRAK
Tujuan dari penelitian ini adalah untuk; (1) Mengkaji tentang komunikasi interpersonal oleh marketing yang dilakukan Hotel Santika Bogor pada member, (2) Mengkaji brand image Hotel Santika Bogor, (3) Mengkaji hubungan antara komunikasi interpersonal marketing dan member dengan brand image Hotel Santika Bogor. Jenis penelitian yang digunakan adalah metode penelitian asosiatif dengan pendekatan kuantitatif. Populasi dalam penelitian ini adalah 50 tamu repeater yang menginap di Hotel Santika Bogor. Populasi ini diperoleh dari database Hotel Santika Bogor, sehingga merupakan populasi finit (terbatas). Sampel yang diambil dalam penelitian ini diambil dari populasi yang telah diketahui dari database repeater (populasi finit) Hotel Santika Bogor, yaitu sebesar 50 sampel. Teknik sampling yang digunakan adalah teknik jenuh atau sensus yaitu dengan mengambil seluruh populasi yang ada. Hasil perhitungan uji signifikansi diperoleh harga $t_{\text {hitung }}$ sebesar 6,202 dan $t_{\text {tabel }}$ untuk kesalahan 0,05 dengan uji dua pihak, dan $\mathrm{dk}=\mathrm{n}-2=48$ diperoleh 2,021. Hal ini berarti terdapat hubungan yang positif dan signifikan komunikasi interpersonal marketing dan member dengan brand image Hotel Santika Bogor. Kontribusi faktor komunikasi interpersonal marketing dan member terhadap brand image adalah 44,5\% sedangkan 55,5\% lainnya dipengaruhi faktor lain, seperti diferensiasi produk, penggunaan celebrity endorser, event sponshorship, brand ambassador, kepemimpinan, dan keunggulan produk.
\end{abstract}

Kata kunci: Komunikasi Interpersonal, Brand Image 
M Qodriyyah, Sukarelawati, AA Kusumadinata. 2015. Hubungan Antara Komunikasi Interpersonal Marketing Dan Member Dengan Brand Image Hotel Santika Bogor. Jurnal Komunikatio 1(2): 61-71. 


\section{PENDAHULUAN}

Hotel Santika Bogor yang tergabung dalam group Santika Indonesia Hotels \& Resorts, dikelola oleh PT. Grahawita Santika. PT. Grahawita Santika didirikan untuk mengelola bisnis perhotelan di bawah Kelompok Kompas Gramedia pada tanggal 22 Agustus 1981. Awalnya Hotel Santika ini terletak di Jalan Sumatra No. 52-54, Bandung. Hotel Santika Bandung yang berbintang tiga pada tanggal 27 Maret 1989 menjadi pelopor berdirinya Santika Indonesia Hotel \& Resort. Sedangkan Hotel Santika Bogor mulai beroperasi pada tanggal 19 Desember 2008 dan peresmian pembukaannya dilaksanakan pada tanggal 5 Februari 2009.

Hotel Santika Bogor menawarkan "HOSPITALITY FROM THE HEART" yang akan melayani pelanggan dengan keramahtamahan, yang terletak di jantung kota Bogor, 500 meter dari pintu tol, 200 meter dari Kebun Raya Bogor, bersebelahan dengan pusat pembelanjaan terbesar di Bogor, serta dekat dengan ibu kota Jakarta yang lebih kurang dapat di tempuh dalam waktu satu jam perjalanan. Dibangun dengan gaya modern minimalis dengan jumlah kamar sebanyak 153 kamar dengan tipe kamar Superior, Deluxe Suite, Executive, Suite dan Presidential Suite room.

Hotel Santika Bogor merupakan hotel bintang 3 (tiga) yang memiliki strategi dalam mengelola hubungan dengan pelanggan sehingga dimungkinkan akan dapat menciptakan citra positif dimata para pelanggan. Untuk itu Public Relations Hotel Santika Bogor berupaya untuk membangun hubungan baik dengan pelanggan melalui strategi komunikasi yang dijalankan organisasi untuk mencapai tujuan menjalin hubungan yang harmonis dengan publik-publik dan stakeholder-nya khususnya pelanggan regulare yang berasal dari perusahaan atau instansi pemerintah.

Hotel Santika Bogor memiliki strategi dalam membangun hubungan dengan pelanggan guna menciptakan citra positif dimata para pelanggan. Public Relations Hotel Santika Bogor melalui marketing berupaya untuk membangun hubungan baik dengan pelanggan melalui strategi komunikasi yang dijalankan organisasi untuk mencapai tujuan menjalin hubungan yang harmonis dengan pelanggan. Strategi dan program marketing Hotel Santika Bogor dalam mengelola hubungan komunikasi dimungkinkan mampu meningkatkan citra baik perusahaan dimata pelanggan, serta menjadi hal yang sangat penting dalam mencapai tujuan perusahaan. Hal ini sangat menarik penulis untuk melakukan penelitian yang mendalam.

Berdasarkan uraian tersebut, mendorong penulis untuk melakukan penelitian dengan judul "Hubungan antara Komunikasi Interpersonal Marketing dan Member dengam Brand Image Hotel Santika bagi Member".

Dari uraian latar belakang permasalahan, maka dalam penelitian ini dirumuskan masalah yang menjadi kajian penelitian. Perumusan masalah dalam penelitian ini, adalah :

1. Bagaimana komunikasi interpersonal oleh marketing yang dilakukan Hotel Santika Bogor pada member?

2. Bagaimana brand image Hotel Santika Bogor?

3. Bagaimana hubungan antara komunikasi interpersonal marketing dan member dengam brand image Hotel Santika bagi member?

\section{Kerangka Pemikiran}

Suatu perusahaan sangat memerlukan adanya komunikasi timbal balik untuk mencapai tujuannya, terjalinnya komunikasi timbal balik tersebut dapat dilakukan dengan adanya public relations. Artinya menjadi hal yang utama bagi public relations untuk mampu mengemban fungsi dan tugasnya dalam melaksanakan hubungan komunikasi ke dalam, yaitu upaya membina hubungan yang harmonis antara pimpinan manajemen dengan para karyawan, dan antara pimpinan dengan pemilik perusahaan atau sebaliknya. Begitu juga kemampuannya untuk menjembatani atau membangun hubungan komunikasi dengan masyarakat luar sebagai publiknya yang pada akhirnya dapat menentukan sukses atau tidaknya tujuan dan citra yang hendak dicapai oleh perusahaan.

Sesuai dengan kerangka berpikir pada gambar 1 yang menjadi variabel bebas adalah komunikasi (X). Variabel terikat adalah brand image (Y). Jika proses tersebut digambarkan dalam suatu bagan, pada Gambar1. 
Gambar 1. Kerangka Pemikiran

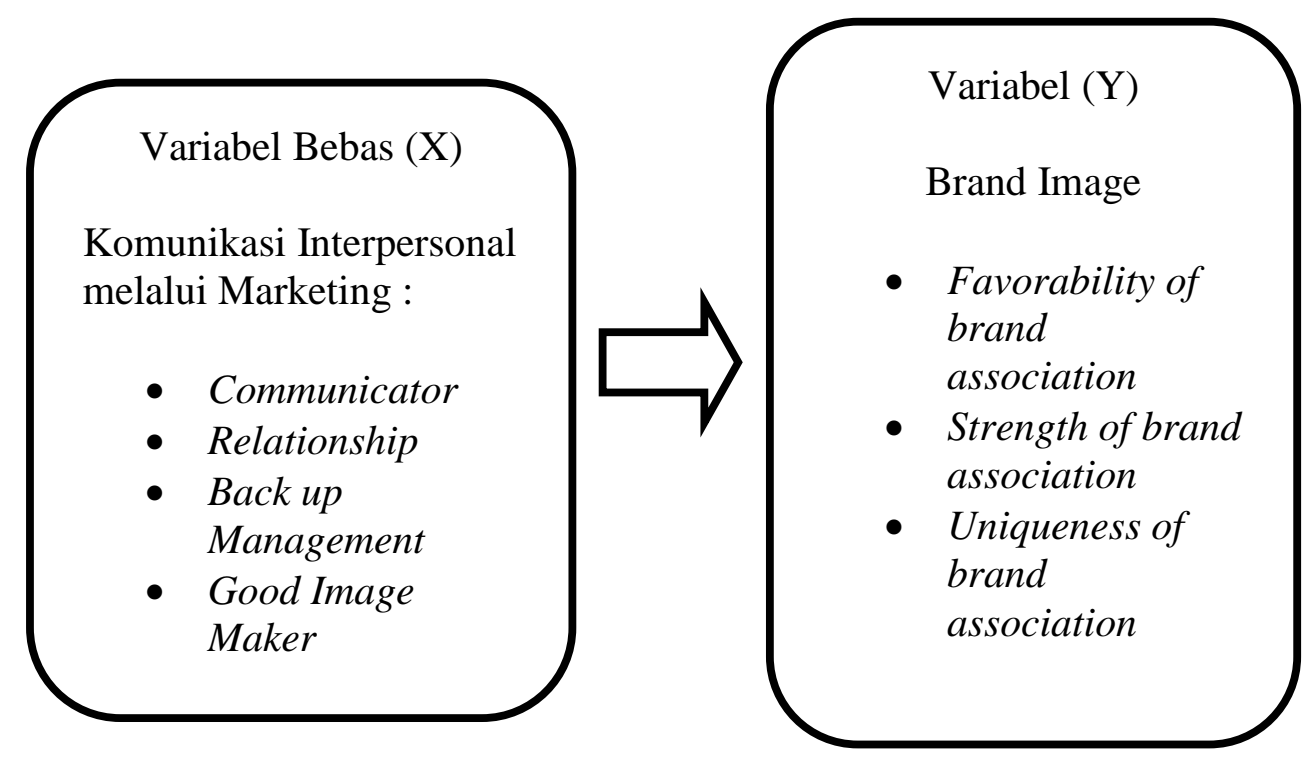

\section{Hipotesis:}

Pada penelitian ini, maka dapat ditarik suatu hipotesis yaitu, Komunikasi interpersonal

\section{METODE PENELITIAN}

\section{Pemilihan Metode}

Jenis penelitian yang digunakan adalah metode penelitian asosiatif dengan pendekatan kuantitatif. Sugiyono (2008) menyatakan permasalahan asosiatif, adalah suatu pertanyaan yang bersifat menghubungkan dua variabel atau lebih. Metode ini bertujuan menggambarkan sifat obyek penelitian pada saat riset sedang berlangsung dan mencoba untuk menemukan hubungan antara masing-masing variabel yang diteliti, dimana penulis mencoba membagi menjadi beberapa variabel, yaitu : variabel bebas/komunikasi, sedangkan variabel terikat/brand image.

\section{Teknik Pengambilan Sampel}

\section{a. Populasi}

Populasi dalam penelitian ini adalah 50 tamu repeater yang menginap di Hotel Santika Bogor. Populasi ini diperoleh dari database Hotel Santika Bogor. Sehingga merupakan populasi finit (terbatas)

b. Sampel

Dalam penelitian ini, teknik sampling yang digunakan adalah teknik jenuh atau sensus marketing dan member berhubungan nyata dengan brand image Hotel Santika Bogor bagi member.

yaitu dengan mengambil seluruh populasi yang ada. Sampling jenuh atau sensus adalah teknik penentuan sampel bila semua anggota populasi digunakan sebagai sampel. Sampel yang diambil dalam penelitian ini diambil dari populasi yang telah diketahui dari database repeater (populasi finit) Hotel Santika Bogor, yaitu sebesar 50 sampel.

Pertimbangan sampel dalam penelitian ini adalah tamu yang menginap minimal dua kali dalam 6 bulan terakhir (1 September $2013-1$ Februari 2014) di Hotel Santika Bogor usia 18 tahun ke atas sampai batas maksimum 65 tahun. Penulis mengambil range usia tersebut karena merujuk pada pelanggan Hotel Santika Bogor yang rata-rata berumur 18 tahun sampai 65 tahun.

\section{Teknik Analisis Data}

Data dalam penelitian ini dianalisis dengan menggunakan beberapa prosedur statistik. Untuk mengetahui kriteria penafsiran dihitung dengan menggunakan sistem skoring, dalam penelitian ini skala pengukurannya menggunakan rumus Bakrie Siregar (1981) weight mean score (WMS) yaitu dengan dilakukan pembobotan nilai untuk setiap 
jawaban, dengan interval $1-5$, sehingga data dari pengisian kuesioner disajikan dalam bentuk distribusi frekuensi dan tabulasi silang serta data yang diperoleh berskala interval dan ordinal.

Stanford Labovits Research dalam Siregar (1981) digunakan untuk mengemukakan dan memperoleh angka penafsiran dipergunakan rumus :

$$
\mathrm{M}=\frac{\Sigma \mathrm{f}(\mathrm{X})}{\mathrm{n}}
$$

Dimana :

$\mathrm{M}=$ Perolehan angka kriteria penafsiran

$\mathrm{f}=$ Frekuensi Jawaban

$\mathrm{x}=$ Pembobotan (skala nilai)

$\sum=$ Penjumlahan

$\mathrm{n}=$ Jumlah sampel penelitian.

Untuk menganalisis data yang diperoleh secara deskriptif, penulis menggunakan analisis statistik deskriptif berupa frekuensi, presentase, rataan, rataan skor dan total rataan skor melalui rumus WMS (weight mean score). Untuk menganalisis hubungan variabel $\mathrm{x}$ (komunikasi) dan variabel y (brand image) penulis menggunakan Skala Likert yang bertujuan untuk mengkualifikasi data dari reliabilitasnya suatu variabel melalui data ordinal dan interval dengan menggunakan uji Rank Order Spearman (Kros) menurut Sugiyono (2006) untuk mengukur hubungan kedua variabel tersebut digunakan rumus sebagai berikut:

\section{HASIL DAN PEMBAHASAN}

Untuk menjawab rumusan masalah dari penelitian ini, yaitu untuk mengkaji komunikasi interpersonal antara marketing dan member dengan brand image Hotel Santika Bogor,

$$
P=\frac{1-6 \sum d_{1}^{2}}{n\left(n^{2}-1\right)}
$$

Dimana:

$\mathrm{P}=$ Koefisien korelasi Rank Spearman

$\mathrm{d}=$ Kuadrat beda antara rank $\mathrm{x}$ dan $\mathrm{y}$

$\mathrm{n}=$ Ukuran / jumlah populasi atau ukuran sampel

$\Sigma=$ Jumlah

Sedangkan untuk mencari hubungan kedua variabel menggunakan rumus uji hipotesis sebagai berikut (Sugiyono, 2006)

$t_{\text {hitung }}=\frac{r_{x y} \sqrt{n-2}}{\sqrt{1-{r_{x y}}^{2}}}$

Keterangan:

$\mathrm{t}=$ Tes kriteria

$\mathrm{n}=$ Jumlah pertanyaan dalam kuesioner

$\mathrm{r}=$ Korelasi

$\mathrm{x}=$ Variabel $\mathrm{X}$

$\mathrm{y}=$ variabel $\mathrm{Y}$

Untuk menguji hipotesis tersebut, $t_{\text {hitung }}$ dibandingkan dengan $t_{\text {tabel }}$ pada $\alpha=0,01$ kriteria hasil pengujian sebagai berikut:

1. Bila $t_{\text {hitung }}>t_{\text {tabel, }}$ maka $\mathrm{H}_{0}$ ditolak, $\mathrm{H}_{\mathrm{a}}$ diterima berarti terdapat hubungan yang signifikan antara komunikasi interpersonal marketing dan member dengan brand image pada Hotel Santika Bogor

2. Bila $t_{\text {hitung }}<t_{\text {tabel}}$, maka $H_{0}$ diterima, $H_{a}$ ditolak berarti tidak terdapat hubungan yang signifikan antara komunikasi interpersonal marketing dan member dengan brand image pada Hotel Santika Bogor

dilakukan analisis deskriptif yang diperoleh dari hasil penyebaran kuesioner.

Berdasarkan hasil dari tabulasi data, maka pelaksanaan komunikasi interpersonal antara marketing dengan member pada Hotel Santika Bogor dapat dilihat pada tabel berikut ini. 
Tabel 1. Rekapitulasi Tanggapan Responden tentang Komunikasi Interpersonal antara Marketing dengan Member pada Hotel Santika Bogor

\begin{tabular}{|c|c|c|c|}
\hline No. & Aspek yang Diukur/Dimensi & $\mathbf{M}$ & Kesimpulan \\
\hline 1. & Communicator & 4,06 & \multirow{4}{*}{ 4,04 (Baik) } \\
\hline 2. & Relationship & 4,11 & \\
\hline 3. & Back up Management & 4,06 & \\
\hline 4. & Good Image Maker & 3,95 & \\
\hline \multicolumn{2}{|r|}{ Jumlah } & 16,18 & \\
\hline
\end{tabular}

Sumber: Diolah dari data responden

Tabel 1. di atas, didapat angka penafsiran sebesar 4,04 dengan kriteria penilaian adalah baik. Artinya pelaksanaan komunikasi interpersonal antara marketing dengan member pada Hotel Santika Bogor sudah berjalan dengan baik. Semua aspek yang diukur memiliki kriteria penilaian yang baik. Hal ini perlu dipertahankan, dan untuk aspek good image maker perlu ditingkatkan terutama dalam hal memberikan informasi yang akurat dan dapat dipercaya kepada member tentang kondisi hotel yang sebenarnya.

Berdasarkan hasil dari tabulasi data, maka brand image Hotel Santika Bogor dapat dilihat pada tabel berikut ini.

Tabel 2. Rekapitulasi Tanggapan Responden tentang Brand Image Hotel Santika Bogor

\begin{tabular}{|r|l|c|c|}
\hline No. & \multicolumn{1}{|c|}{ Aspek yang Diukur/Indikator } & M & Kesimpulan \\
\hline \hline 1. & Favorability of brand association & 3,97 & \multirow{2}{*}{3,98} \\
\cline { 1 - 2 } 2. & Strength of brand association & 3,89 & \multirow{2}{*}{ (Baik) } \\
\cline { 1 - 2 } 3. & Uniqueness of brand association & 11,95 & \\
\cline { 1 - 2 } & \multirow{2}{*}{ Jumlah } & & \\
\hline
\end{tabular}

Sumber: Diolah dari data responden

Dari Tabel 2. di atas, didapat angka penafsiran sebesar 3,98 dengan kriteria penilaian adalah baik. Artinya brand image Hotel Santika Bogor menurut tanggapan member (pelanggan) hotel adalah baik.
Untuk lebih jelasnya tentang hasil dari kedua variabel tersebut, maka dapat dilihat pada tabel 3 berikut: 
Tabel 3. Tabel Rekapitulasi Variabel Bebas Komunikasi Interpersonal antara Marketing dengan Member dan Variabel Terikat Brand Image

\begin{tabular}{|l|c|c|}
\hline \multicolumn{1}{|c|}{ Variabel } & Angka Penafsiran & Kriteria \\
\hline \hline $\begin{array}{l}\text { 1. Komunikasi Interpersonal antara Marketing } \\
\text { dengan Member }\end{array}$ & 4,04 & Baik \\
\hline 2. Brand Image & 3,98 & Baik \\
\hline
\end{tabular}

Komunikasi interpersonal antara marketing dengan member dan brand image Hotel Santika Bogor secara umum mendapat penilaian yang baik oleh responden.

Untuk menentukan ada tidaknya hubungan antara komunikasi interpersonal antara marketing dan member dengan brand image Hotel Santika Bogor, maka perlu dilakukan pengujian hipotesis. Untuk itu terlebih dahulu dihitung nilai koefisien antara komunikasi interpersonal antara marketing dan member dengan brand image, penulis menggunakan rumus korelasi Rank Spearman dan Uji Rank Spearman Berganda. Sebagai persiapan untuk menghitung koefisien maka terlebih dahulu dibuat tabel silang untuk mengetahui hubungan antara variabel $\mathrm{x}$ (komunikasi interpersonal antara marketing dan member) dengan variabel y (brand image) berdasarkan hasil uji korelasi diperoleh hasil sebagai berikut pada tabel 4;

Tabel 4. Hubungan antara Komunikasi Interpersonal antara Marketing dan Member dengan Brand Image

\begin{tabular}{|l|c|c|c|}
\hline \multirow{2}{*}{$\begin{array}{l}\text { Komunikasi } \\
\text { Marketing dan Member }\end{array}$} & $\begin{array}{c}|c| \\
\text { Favorability of brand } \\
\text { association }\end{array}$ & $\begin{array}{c}\text { Strength of brand } \\
\text { association }\end{array}$ & $\begin{array}{c}\text { Uniqueness of brand } \\
\text { association }\end{array}$ \\
\hline Communicator & $0,357^{*}$ & $0,308^{*}$ & $0,281^{*}$ \\
\hline Relationship & $0,360^{*}$ & $0,338^{*}$ & 0,233 \\
\hline Back up Management & $0,721^{* *}$ & $0,566^{* *}$ & $0,509^{* *}$ \\
\hline Good Image Maker & $0,337^{*}$ & $0,703^{* *}$ & $0,382^{* *}$ \\
\hline
\end{tabular}

Sumber : Hasil Penghitungan SPSS versi 20 (2014)

Keterangan $\quad:{ }^{* *}$ berhubungan nyata pada taraf 0,01

* berhubungan nyata pada taraf 0,05

Data pada Tabel 4. menunjukkan communicator sebagai faktor komunikasi interpersonal antara marketing dan member yang mempengaruhi brand image berkorelasi signifikan dengan indikator favorability of brand association, strength of brand association, dan uniqueness of brand association. Hal ini dapat diasumsikan bahwa menurut persepsi pelanggan Hotel Santika Bogor, brand image Hotel Santika Bogor dapat meningkat jika marketing memiliki kemampuan sebagai komunikator dengan baik. Indikator communicator berkorelasi signifikan dengan indikator favorability of brand association, strength of brand association, dan uniqueness of brand association yang merupakan semua indikator dalam variabel brand image. Kemampuan marketing dalam berkomunikasi baik secara langsung maupun tidak langsung dengan member berpengaruh terhadap kepercayaan pelanggan bahwa atribut dan manfaat yang diberikan oleh merek akan dapat memenuhi atau memuaskan kebutuhan dan keinginannya sehingga membentuk sikap 
positif pelanggan terhadap merek. Kemampuan marketing dalam berkomunikasi baik secara langsung maupun tidak langsung dengan member juga berpengaruh terhadap bagaimana informasi masuk kedalam ingatan konsumen dan bagaimana proses bertahan sebagai bagian dari citra merek. Kemampuan marketing dalam berkomunikasi baik secara langsung maupun tidak langsung dengan member berpengaruh terhadap penciptaan keunggulan bersaing yang dapat dijadikan alasan bagi pelanggan untuk memilih suatu merek tertentu.

Indikator relationship sebagai faktor komunikasi interpersonal antara marketing dan member yang mempengaruhi brand image berkorelasi signifikan dengan indikator favorability of brand association dan strength of brand association. Hal ini dapat diasumsikan bahwa menurut persepsi pelanggan Hotel Santika Bogor, brand image Hotel Santika Bogor dapat meningkat jika marketing membangun hubungan yang positif antara lembaga yang diwakilinya dengan public internal dan eksternal dengan baik. Indikator relationship berkorelasi signifikan dengan indikator favorability of brand association dan strength of brand association. Kemampuan marketing dalam membangun hubungan yang positif antara lembaga yang diwakilinya dengan public internal dan eksternal berpengaruh terhadap kepercayaan pelanggan bahwa atribut dan manfaat yang diberikan oleh merek akan dapat memenuhi atau memuaskan kebutuhan dan keinginannya sehingga membentuk sikap positif pelanggan terhadap merek. Kemampuan marketing dalam membangun hubungan yang positif antara lembaga yang diwakilinya dengan public internal dan eksternal juga berpengaruh terhadap bagaimana informasi masuk kedalam ingatan konsumen dan bagaimana proses bertahan sebagai bagian dari citra merek.

Hasil penelitian juga menyebutkan bahwa indikator relationship sebagai faktor komunikasi interpersonal antara marketing dan member yang mempengaruhi brand image tidak berkorelasi dengan indikator uniquenessof brand association. Hal ini dapat diasumsikan bahwa menurut persepsi pelanggan Hotel Santika Bogor, kemampuan marketing dalam membangun hubungan yang positif antara lembaga yang diwakilinya dengan public internal dan eksternal tidak berpengaruh terhadap kepercayaan pelanggan akan kesan unik dan perbedaan yang berarti diantara brand lain sehingga tidak bisa membuat pelanggan "tidak mempunyai alasan untuk tidak" untuk memilih brand tersebut.

Indikator Back up Management sebagai faktor komunikasi interpersonal antara marketing dan member yang mempengaruhi brand image berkorelasi signifikan dengan indikator favorability of brand association, strength of brand association, dan uniqueness of brand association. Hal ini dapat diasumsikan bahwa menurut persepsi pelanggan Hotel Santika Bogor, brand image Hotel Santika Bogor dapat meningkat jika marketing memiliki kemampuan melakukan dukungan manajemen atau menunjang kegiatan dari divisi lain untuk mencapai tujuan bersama dalam suatu kerangka tujuan pokok perusahaan/organisasi dengan baik. Indikator communicator berkorelasi signifikan dengan indikator favorability of brand association, strength of brand association, dan uniqueness of brand association yang merupakan semua indikator dalam variabel brand image. Kemampuan marketing dalam melakukan dukungan manajemen atau menunjang kegiatan dari divisi lain berpengaruh terhadap kepercayaan pelanggan bahwa atribut dan manfaat yang diberikan oleh merek akan dapat memenuhi atau memuaskan kebutuhan dan keinginannya sehingga membentuk sikap positif pelanggan terhadap merek. Kemampuan marketing dalam melakukan dukungan manajemen atau menunjang kegiatan dari divisi lain juga berpengaruh terhadap bagaimana informasi masuk kedalam ingatan konsumen dan bagaimana proses bertahan sebagai bagian dari citra merek. Kemampuan marketing dalam melakukan dukungan manajemen atau menunjang kegiatan dari divisi lain berpengaruh terhadap penciptaan keunggulan bersaing yang dapat dijadikan alasan bagi pelanggan untuk memilih suatu merek tertentu.

Indikator good image maker sebagai faktor komunikasi interpersonal antara marketing dan member yang mempengaruhi brand image berkorelasi signifikan dengan indikator favorability of brand association, strength of brand association, dan uniqueness of brand association. Hal ini dapat diasumsikan bahwa menurut persepsi pelanggan Hotel Santika Bogor, brand image Hotel Santika Bogor dapat meningkat jika marketing memiliki 
kemampuan menciptakan citra atau publikasi yang positif dalam rangka membangun citra atau nama baik hotel yang diwakilinya dengan baik. Indikator good image maker berkorelasi signifikan dengan indikator favorability of brand association, strength of brand association, dan uniqueness of brand association yang merupakan semua indikator dalam variabel brand image. Kemampuan marketing dalam menciptakan citra atau publikasi yang positif dalam rangka membangun citra atau nama baik hotel yang diwakilinya berpengaruh terhadap kepercayaan pelanggan bahwa atribut dan manfaat yang diberikan oleh merek akan dapat memenuhi atau memuaskan kebutuhan dan keinginannya sehingga membentuk sikap positif pelanggan terhadap merek. Kemampuan marketing dalam menciptakan citra atau publikasi yang positif dalam rangka membangun citra atau nama baik hotel yang diwakilinya juga berpengaruh terhadap bagaimana informasi masuk kedalam ingatan konsumen dan bagaimana proses bertahan sebagai bagian dari citra merek. Kemampuan marketing dalam menciptakan citra atau publikasi yang positif dalam rangka membangun citra atau nama baik hotel yang diwakilinya berpengaruh terhadap penciptaan keunggulan bersaing yang dapat dijadikan alasan bagi pelanggan untuk memilih suatu merek tertentu.

Dengan demikian dapat diasumsikan bahwa komunikasi interpersonal antara marketing dan member berkorelasi signifikan dan menunjukkan indikasi positif dengan brand image.

Untuk mengetahui bagaimana hubungan antara komunikasi interpersonal antara marketing dan member dengan brand image, maka untuk perhitungannya digunakan uji rank spearman berganda sebagaimana dapat dilihat pada tabel berikut ini.

Tabel 5. Hasil SPSS Versi 20 untuk Hubungan antara Komunikasi Interpersonal Marketing dan Member dengan Brand Image

Correlations

\begin{tabular}{|lll|r|r|}
\hline & & kom unikasi & brand image \\
\hline Spearman's rho & kom unikasi & Correlation Coefficient & 1.000 & $.667^{* *}$ \\
& & Sig. (2-tailed) & .000 \\
& $\mathrm{~N}$ & 50 & 50 \\
\cline { 2 - 5 } & brand image & Correlation Coefficient & $.667^{* *}$ & 1.000 \\
& & Sig. (2-tailed) & .000 &. \\
& & 50 & 50 \\
\hline
\end{tabular}

${ }^{\star *}$. Correlation is significant at the 0.01 level (2-tailed).

Sumber : Hasil Penghitungan SPSS versi 20 (2014)

Keterangan $\quad:{ }^{* *}$ berhubungan nyata pada taraf 0,01

* berhubungan nyata pada taraf 0,05

Berdasarkan Tabel 5. di atas, analisis korelasi Rank Spearman Berganda antara komunikasi interpersonal marketing dan member (variabel $\mathrm{X}$ ) dengan brand image (variabel Y), mendapatkan nilai koefisien korelasi sebesar $0,667^{* *}$. Karena koefisien mendekati 1, maka dapat disimpulkan bahwa hubungan antara komunikasi interpersonal marketing dan member dengan brand imagei adalah cukup erat. Jika dilihat pada pedoman interpretasi koefisien korelasi ( $r$ ) nilai $r$ hitung yang didapat sebesar $0,667^{* *}$ terletak di wilayah antara 0,600 - 0,799 yakni berada di level kuat. Maka dapat disimpulkan bahwa korelasi diantara kedua variabel yaitu komunikasi interpersonal marketing dan member (variabel
X) dengan brand image (variabel Y) memiliki hubungan yang kuat dan menunjukkan hubungan positif, artinya jika komunikasi interpersonal marketing dan member baik, maka brand image hotel juga tinggi.

Untuk menentukan diterima atau ditolaknya hipotesis maka dilakukan pengujian signifikansi koefisien korelasi dengan rumus ttest, yaitu: 


$$
\begin{aligned}
t_{\text {hitung }} & =\frac{r s \sqrt{n-2}}{\sqrt{1-r s^{2}}} \\
& =\frac{0,667 \sqrt{50-2}}{\sqrt{1-0,667^{2}}} \\
& =\frac{(0,667)(6,928)}{\sqrt{1-0,445}} \\
& =\frac{4,621}{0,745} \\
& =6,202
\end{aligned}
$$

Berdasarkan hasil perhitungan di atas dapat disimpulkan bahwa korelasi antara kedua variabel adalah 0,667. Hasil perhitungan uji signifikansi, diperoleh harga $t_{\text {hitung }}$ sebesar 6,202. Harga tersebut selanjutnya dikonsultasikan dengan $t_{\text {tabel }}$ untuk kesalahan 0,05 dengan uji dua pihak, dan $\mathrm{dk}=\mathrm{n}-2=48$, maka diperoleh $t_{\text {tabel }}=2,021$. Hal ini berarti nilai $t_{\text {hitung }}$ lebih besar dari nilai $t_{\text {tabel }}(6,202>$ 2,021) sehingga dapat disimpulkan terdapat hubungan yang positif dan signifikan antara komunikasi interpersonal marketing dan member dengan brand image Hotel Santika Bogor.

Selanjutnya untuk mencari besarnya hubungan komunikasi interpersonal marketing dan member dengan brand image Hotel Santika Bogor dapat ditentukan dengan menghitung koefisien determinasi dengan rumus sebagai berikut:

$$
\begin{aligned}
\mathrm{Kd} & =\mathrm{rs}^{2} \times 100 \% \\
& =0,667^{2} \times 100 \% \\
& =0,4449 \times 100 \% \\
& =44,5 \%
\end{aligned}
$$

Dengan demikian kontribusi dari faktor komunikasi interpersonal marketing dan member terhadap brand image adalah 44,5\%.

\section{KESIMPULAN DAN SARAN}

\section{KESIMPULAN}

Berdasarkan hasil penelitian yang telah dilakukan, dapat ditarik beberapa kesimpulan untuk menjawab perumusan masalah sebelumnya, yaitu :

Berdasarkan hasil penelitian untuk variabel komunikasi interpersonal marketing dan member, dapat disimpulkan bahwa bagian marketing sudah melaksanakan komunikasi interpersonal pada member dengan baik. Hal ini terbukti dengan perolehan angka penafsiran sebesar 4,04 dengan kriteria penilaian baik. Pelaksanaan komunikasi interpersonal antara marketing dengan member pada Hotel Santika Bogor sudah berjalan dengan baik. Semua aspek yang diukur memiliki kriteria penilaian yang baik.

Berdasarkan hasil penelitian untuk variabel brand image Hotel Santika Bogor, dapat disimpulkan bahwa menurut pelanggan (member) hotel, brand image Hotel Santika Bogor adalah baik. Terbukti dengan perolehan angka penafsiran sebesar 3,98 dengan kriteria penilaian baik.

Berdasarkan hasil tabel silang hubungan antara variabel $\mathrm{x}$ (komunikasi interpersonal antara marketing dan member) dengan variabel y (brand image) diperoleh hasil semua indikator variabel $\mathrm{x}$ (komunikasi interpersonal antara marketing dan member) memiliki korelasi dengan indikator variabel y (brand image). Hanya indikator relationship sebagai faktor komunikasi interpersonal antara marketing dan member yang mempengaruhi brand image tidak berkorelasi dengan indikator uniquenessof brand association. Hal ini dapat diasumsikan bahwa menurut persepsi pelanggan Hotel Santika Bogor, kemampuan marketing dalam membangun hubungan yang positif antara lembaga yang diwakilinya dengan public internal dan eksternal tidak berpengaruh terhadap kepercayaan pelanggan akan kesan unik dan perbedaan yang berarti diantara brand lain sehingga tidak bisa membuat pelanggan "tidak mempunyai alasan untuk tidak" untuk memilih brand tersebut.

Hasil perhitungan uji signifikansi diperoleh harga $t_{\text {hitung }}$ sebesar 6,202 dan $t_{\text {tabel }}$ untuk kesalahan 0,05 dengan uji dua pihak, dan $\mathrm{dk}=$ $\mathrm{n}-2=48$ diperoleh 2,021. Hal ini berarti terdapat hubungan yang positif dan signifikan komunikasi interpersonal marketing dan member dengan brand image Hotel Santika Bogor. Kontribusi faktor komunikasi interpersonal marketing dan member terhadap brand image adalah 44,5\% sedangkan 55,5\% lainnya dipengaruhi faktor lain seperti diferensiasi produk, penggunaan celebrity endorser, event sponshorship, brand ambassador, kepemimpinan, dan keunggulan produk.

\section{SARAN}


Perlunya mempertahankan komunikasi interpersonal marketing dan member terutama dalam hal memberikan informasi yang akurat dan dapat dipercaya kepada member tentang kondisi hotel yang sebenarnya.

Pihak manajemen Hotel Santika Bogor perlu memperhatikan perawatan fasilitas yang ada di Hotel Santika Bogor karena faktor ini mendapat penilaian yang paling kecil menurut responden. Dalam hal ini, manajemen hotel dapat meningkatkan pengawasannya pada Chief Engineer, karena merekalah yang bertanggung jawab terhadap pengelolaan dalam hal pemasangan dan pengoperasian mesin-mesin atau peralatan penunjang operasional hotel.

Marketing Hotel Santika Bogor dalam melakukan komunikasi interpersonal dengan member hendaknya selalu mengungkapkan keunikan-keunikan dan hal-hal menarik yang dimiliki Hotel Santika Bogor sehingga member menjadi tahu akan keunikan dan hal-hal menarik hotel tersebut.

Perlunya meningkatkan motivasi kerja pegawai Hotel Santika Bogor agar dapat memberikan pelayanan jasa perhotelan dengan baik sehingga dapat mewujudkan "HOSPITALITY FROM THE HEART" seperti yang ditawarkan hotel tersebut.

Perlunya dilakukan penelitian lanjutan yang membahas tentang faktor-faktor yang dapat mempengaruhi brand image.

\section{DAFTAR PUSTAKA}

Siregar B. 1981. Metode Riset Sosial: Suatu Pengantar. Jakarta (ID).Grasindo.

Sugiyono. 2006. Teknik Penelitian. Yogyakarta (ID): Pines.

Sugiyono. 2008. MetodePenelitian Kuantitatif dan Kualitatif R \& D. Bandung (ID):

Alfabeta. 